\title{
Pengaruh Kompensasi, Lingkungan Kerja, Fasilitas Terhadap Kepuasan Kerja PT ISS Universitas Tarumanagara
}

\author{
Funny dan Oey Hannes Widjaja \\ Program Studi Manajemen Fakultas Ekonomi Universitas Tarumanagara, Jakarta \\ Email: funnyangella23@gmail.com
}

\begin{abstract}
The purpose of this research is to know the impact of compensation, work environment and facilities on employee job satisfication, Method in this study is using causal method with quantitative research and used questionnaire to collected the data. Sample size taken for this research is 100 respondents. This study used software SmartPLS version. By using purposive sampling, findings of the study showed that compensation, work environment and facilities have a positive and significant on employee job satisfication.
\end{abstract}

Keywords: Compesation, Work Enviroment, Facilities, Job Satisfication.

Abstrak: Tujuan dari penelitian ini adalah untuk mengetahui pengaruh kompensasi, lingkungan kerja dan fasilitas terhadap kepuasan kerja karyawan. Metode pada penelitian ini menggunakan metode kausal dengan jenis penelitian kuantitatif dan menggunakan teknik kuesioner untuk mengumpulkan data. Ukuran sampel yang digunakan pada penelitian ini sebanyak 100 responden. Penelitian ini menggunakan SmartPLS. Dengan menggunakan purposive sampling, temuan pada penelitian ini menunjukkan bahwa kompensasi, lingkungan kerja dan fasilitas berpengaruh positif dan signifikan terhadap kepuasan kerja karyawan.

Kata Kunci: Kompensasi, Lingkungan Kerja, Fasilitas dan Kepuasan Kerja.

\section{LATAR BELAKANG}

Setiap perusahaan pada umumnya memiliki satu tujuan yang sama yaitu mencapai keuntungan dan berusaha untuk mempertahankan kelangsungan hidup perusahaan dalam jangka waktu yang panjang. Untuk itu perusahaan perlu memperhatikan seluruh aspek yang berkaitan dengan kelangsungan hidup perusahaan. Salah satu aspek yang sangat penting bagi perusahaan dan perlu diperhatikan adalah sumber daya manusia. Karena apabila perusahaan memiliki teknologi yang baik tetapi tidak di dukung oleh sumber daya manusia yang berkualitas maka perusahaan tidak dapat berjalan dengan baik. Jadi dapat dikatakan bahwa sumber daya manusia merupakan kunci dari keberhasilan suatu perusahaan.

Kepuasan kerja karyawan dapat mencerminkan perasaan karyawan terhadap pekerjaannya. Hal tersebut cukup penting karena kepuasan kerja seseorang dapat meningkatkan loyalitas seseorang dalam melakukan pekerjaannya. Karyawan yang memiliki kepuasan kerja yang besar di dalam pekerjaannya tentunya dapat tercermin pada kinerja dalam menjalankan tugasnya dibandingkan dengan karyawan yag tidak memiliki kepuasan kerja di dalam pekerjaannya. 
Kompensasi meliputi semua bentuk bayaran yang diberikan kepada karyawan dan timbul dari hubungan kerja mereka (Dessler, 2017). Terdapat 2 komponen utama dalam hal pemberian kompensasi diantaranya adalah pembayaran langsung dan pembayaran tidak langsung. Kompensasi juga merupakan tanda balas jasa dari perusahaan kepada karyawan atas loyalitas yang diberikan karyawan kepada perusahaan.Penelitian yang dilakukan oleh Pioh \& Tawas,2016 menemukan bahwa kompensasi berpengaruh terhadap kepuasan kerja karyawan. Hal tersebut juga mendorong peneliti untuk melakukan penelitian lebih lanjut terhadap penelitian ini.

Selain kompensasi, faktor yang mempengaruhi kepuasan kerja karyawan adalah lingkungan kerja dan fasilitas. Menurut (Sunyoto, 2013) Lingkungan kerja adalah segala sesuatu yang ada disekitar pekerja dan yang dapat mempengaruhi dirinya dalam menjalankan tugas yang diberikan. Lingkungan kerja juga merupakan hal yang cukup penting di samping kompensasi. Lingkungan kerja yang mendukung juga dapat berpengaruh kepada kepuasan kerja karyawan di suatu perusahaan. Sebaliknya, apabila lingkungan kerja tidak mendukung tentunya akan berdampak kepada kepuasan kerja maupun kierja karyawan di dalam perusahaan.

Selain faktor kompensasi dan lingkungan kerja, faktor yang cukup penting dalam menentukan kepuasan kerja karyawan adalah fasilitas. Dimana fasilitas yang dimaksud bukanlah dalam bentuk materi melainkan dalam bentuk tunjangan atau benefit yang diberikan perusahaan kepada karyawan. Oleh karena itu penulis bermaksud untuk melakukan penelitian untuk melihat seberapa besar pengaruh fasilitas kepada kepuasan kerja karyawan di perusahaan.

\section{KAJIAN TEORI}

Definisi umum Kepuasan kerja menurut (Hasibuan, 1991:222) adalah sikap emosional yang menyenangkan dan mencintai pekerjaannya. Sikap ini dicerminkan oleh moral kerja, kedisplinan, dan prestasi kerja.

Menurut (Nitisemito, 1996:90) Kompensasi adalah balas jasa yang diberikan oleh perusahaan kepada karyawannya, yang dapat dinilai dengan uang dan cenderung diberikan secara tetap.

Menurut (Mundung, 2007) Lingkungan kerja merupakan kondisi di sekitar pekerja yaitu lingkungan kerja, hubungan dengan teman dalam pekerjaan, hubungan dengan supervise, dan hubungan dengan manajemen.

Menurut (Moenir, 2010:19) fasilitas adalah segala bentuk peralatan dan perlengkapan kerja dan pelayanan yang memiliki fungsi sebagai alat untuk membantu karyawan dalam melaksanakan pekerjaannya.

Kerangka pemikiran dalam penelitian ini, dapat digambarkan sebagai berikut: 


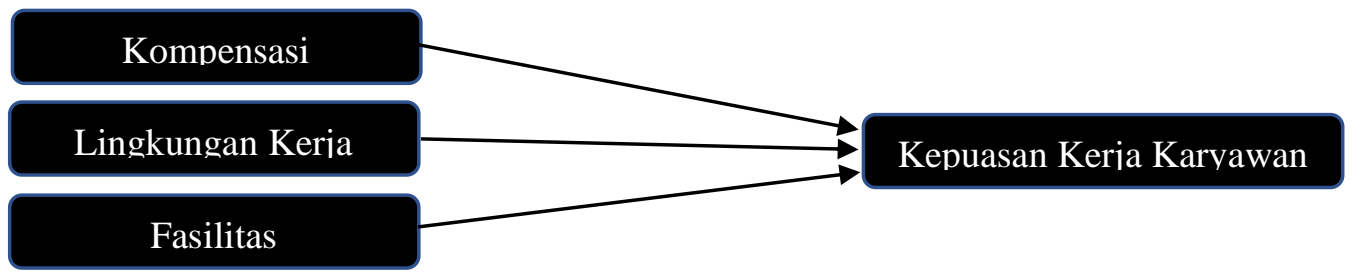

Gambar 1. Kerangka Penelitian

Dengan hipotesis sebagai berikut:

H1 : Terdapat pengaruh positif antara Kompensasi dengan Kepuasan kerja karyawan.

H2 : Terdapat pengaruh positif antara Lingkungan Kerja dengan Kepuasan kerja karyawan.

H3 : Terdapat pengaruh positif antara Fasilitas dengan Kepuasan kerja karyawan.

\section{METODOLOGI}

Hasil penelitian ini didapatkan dari pembagian kuesioner kepada seluruh karyawan PT ISS Indonesia di Universitas Tarumanagara. Penelitian ini berfokus pada kepuasan kerja karyawan tersebut. Pemilihan sampel yang dilakukan menggunakan metode purposive sampling.

Variabel operasional dalam penelitian ini terdiri dari Kompensasi, Lingkungan Kerja dan Fasilitas yang merupakan variabel independen, Kepuasan Kerja karyawan sebagai variabel dependen. Variabel Kompensasi dalam penelitian ini diukur dengan indikator yang diadopsi dari Luthans (2006), Sementara indikator Lingkungan Kerja diadopsi dari Sutrisno (2009), Indikator Fasilitas di adopsi dari Faisal (2005) dan Indikator Kepuasan kerja diadopsi dari Luthans (2006).

Penelitian ini menggunakan skala Likert sebagai pemberian skor dari setiap indikator dan penyebaran kuisioner dilakukan secara manual dengan menggunakan Kuisioner.

\section{HASIL ANALISIS DATA}

Berdasarkan data yang didapat dari 100 (100\%) responden, , maka dapat dijelaskan bahwa karakteristik responden berdasarkan jenis kelamin laki-laki terdapat 64 orang (64\%) dan jenis kelamin perempuan terdapat 36 orang (36\%). Untuk karakteristik berdasarkan yaitu usia > 30 tahun sebanyak 68 orang (68\%), usia 30-40 tahun sebanyak 20 orang (20\%), usia 41-50 tahun sebanyak 12 orang (12\%). Untuk karakteristik berdasarkan pendidikan terakhir, seluruh karyawan di perusahaan tersebut memiliki Pendidikan terakhir tingkat SMA sebanyak 100 orang (100\%). Untuk karakteristik responden berdasarkan status perkawinan terdapat 78 orang $(78 \%)$ sudah menikah dan 22 orang $(22 \%)$ sudah menikah.

Menurut Sekaran and Bogie, 2013:225 Analisis validitas merupakan uji yang dilakukan untuk melihat seberapa tepat sebuah instrumen penelitian dalam penelitian ini adalah kuisioner untuk mengukur suatu konsep yang akan di teliti. Uji validitas dilakukan dengan cara mengukur validitas konvergen, validitas diskriminan dan AVE. 
Funny dan Widjaja: Pengaruh Kompensasi, Lingkungan Kerja...

Tabel 1. Hasil Nilai Average Variance Extracted (AVE)

\begin{tabular}{|c|c|}
\hline Variabel & Average Variance Extracted (AVE) \\
\hline Kompensasi & $\mathbf{0 . 6 4 4}$ \\
\hline Lingkungan Kerja & $\mathbf{0 . 6 6 0}$ \\
\hline Fasilitas & $\mathbf{0 . 6 0 4}$ \\
\hline Kepuasan Kerja & $\mathbf{0 . 5 9 7}$ \\
\hline
\end{tabular}

*Sumber : olahan data Smart-PLS versi 3.00

Menurut Hair et al. (2011) dan Henseler et al. (2009) suatu variabel dapat dikatakan valid apabila memiliki nilai AVE diatas 0.5. Hasil dari AVE menunjukkan nilai sebesar 0.644 untuk variabel kompensasi, 0,660 untuk variabel lingkungan kerja, 0.604 untuk variabel fasilitas, dan 0.597 untuk variabel kepuasan kerja. Selanjutnya, suatu indikator dinyatakan valid jika mempunyai loading factor diatas 0,7 terhadap konstruk yang dituju.

Tabel 2. Hasil Nilai Loading Factor

\begin{tabular}{|c|l|l|}
\hline \multicolumn{2}{|c|}{ Indikator } & $\begin{array}{l}\text { Loading } \\
\text { Factor }\end{array}$ \\
\hline K1 & $\begin{array}{l}\text { Apakah anda setuju bahwa anda mendapatkan gaji yang adil dan } \\
\text { sesuai dengan pekerjaan anda ? }\end{array}$ & 0.863 \\
\hline K2 & $\begin{array}{l}\text { Apakah anda setuju bahwa tunjangan yang di berikan perusahaan } \\
\text { sudah sesuai dengan tugas dan tanggung jawab anda ? }\end{array}$ & 0.819 \\
\hline K3 & $\begin{array}{l}\text { Apakah anda setuju bahwa anda mendapatkan bonus sesuai dengan } \\
\text { pencapaian target realisasi pekerjaan yang anda lakukan ? }\end{array}$ & 0.861 \\
\hline K4 & $\begin{array}{l}\text { Apakah anda setuju bahwa atasan anda memberikan penghargaan } \\
\text { terhadap hasil kerja namun tidak berupa uang ataupun barang ? }\end{array}$ & 0.755 \\
\hline K5 & $\begin{array}{l}\text { Apakah anda setuju bahwa rekanan kerja dalam pelaksanaan } \\
\text { kegiatan dapat menciptaan lingkungan yang nyaman dan saling } \\
\text { mendukung ? }\end{array}$ & 0.757 \\
\hline LK2 & $\begin{array}{l}\text { Apakah anda setuju bahwa anda merasa nyaman terhadap suhu udara } \\
\text { di lingkungan kerja anda ? }\end{array}$ & 0.769 \\
\hline LK3 & $\begin{array}{l}\text { Apakah anda setuju bahwa terdapat gangguan dalam bentuk suara } \\
\text { yang timbul di lingkungan kerja anda ? }\end{array}$ & 0.800 \\
\hline sudah cukup baik ? & 0.799 \\
\hline
\end{tabular}




\begin{tabular}{|c|c|c|}
\hline LK4 & $\begin{array}{l}\text { Apakah anda setuju bahwa anda merasa bebas dari rasa kekhawatiran } \\
\text { dasn merasa aman pada saat anda bekerja? }\end{array}$ & 0.773 \\
\hline LK5 & $\begin{array}{l}\text { Apakah anda setuju bahwa pengaturan peralatan kerja sudah sesuai } \\
\text { dengan anda perlukan? }\end{array}$ & 0.784 \\
\hline LK6 & $\begin{array}{l}\text { Apakah anda setuju bahwa terdapat hubungan baik yang terjalin antar } \\
\text { karyawan dalam lingkungan kerja anda }\end{array}$ & 0.737 \\
\hline F1 & $\begin{array}{l}\text { Apakah anda setuju bahwa fasilitas yang di berikan oleh perusahaan } \\
\text { sudah cukup baik dan sesuai dengan kebutuhan anda? }\end{array}$ & 0.719 \\
\hline $\mathrm{F} 2$ & $\begin{array}{l}\text { Apakah anda setuju bahwa fasilitas yang diberikan oleh perusahaan } \\
\text { membantu anda dalam memaksimalkan hasil kerja? }\end{array}$ & 0.817 \\
\hline F3 & $\begin{array}{l}\text { Apakah anda setuju bahwa fasilitas yang diberikan oleh perusahaan } \\
\text { mudah untuk di gunakan guna membantu kelancaran kerja? }\end{array}$ & 0.770 \\
\hline F4 & $\begin{array}{l}\text { Apakah anda setuju bahwa fasilitas yang diberikan oleh perusahaan } \\
\text { dapat membantu mempercepat proses kerja? }\end{array}$ & 0.764 \\
\hline F5 & $\begin{array}{l}\text { Apakah anda setuju bahwa penempatan dan peletakan fasilitas yang } \\
\text { disediakan di lingkungan kerja sudah baik dan benar? }\end{array}$ & 0.791 \\
\hline KK1 & $\begin{array}{l}\text { Apakah anda setuju bahwa anda mendapatkan sistem upah yang adil } \\
\text { dan sesuai dengan pekerjaan anda? }\end{array}$ & 0.846 \\
\hline KK2 & $\begin{array}{l}\text { Apakah anda setuju bahwa anda menyukai pekerjaan yang memberi } \\
\text { kesempatan untuk menggunakan keterampilan anda? }\end{array}$ & 0.762 \\
\hline KK3 & $\begin{array}{l}\text { Apakah anda setuju bahwa anda mempunyai peluang dalam hal } \\
\text { pengembangan karir di perusahaan anda? }\end{array}$ & 0.811 \\
\hline KK4 & $\begin{array}{l}\text { Apakah anda setuju bahwa atasan anda memperikan pengaruh positif } \\
\text { terhadap pekerjaan yang anda lakukan? }\end{array}$ & 0.801 \\
\hline KK5 & $\begin{array}{l}\text { Apakah anda setuju bahwa rekan kerja anda saling membantu dalam } \\
\text { lingkungan kerja? }\end{array}$ & 0.788 \\
\hline
\end{tabular}

*Sumber : olahan data Smart-PLS versi 3.00

Berdasarkan hasil dari Tabel 2, telah menunjukkan bahwa seluruh indikator memiliki nilai loading factor di atas 0,6 di mana telah memenuhi syarat convergent validity (Hair et 
al., 2011), sehingga dapat disimpulkan bahwa semua variabel yang ada dalam penelitian ini dapat digunakan.

Tabel 3. Hasil Pengujian Reliabilitas

\begin{tabular}{|c|c|c|}
\hline Variabel & Cronbach's Alpha & Composite Reliability \\
\hline Kompensasi & $\mathbf{0 . 8 7 0}$ & $\mathbf{0 . 9 0 6}$ \\
\hline Lingkungan Kerja & $\mathbf{0 . 8 6 9}$ & $\mathbf{0 . 9 0 2}$ \\
\hline Fasilitas & $\mathbf{0 . 8 3 2}$ & $\mathbf{0 . 8 8 1}$ \\
\hline Kepuasan Kerja & $\mathbf{0 . 8 6 1}$ & $\mathbf{0 . 9 0 0}$ \\
\hline
\end{tabular}

*Sumber : olahan data Smart-PLS versi 3.00

Berdasarkan hasil pengujian reliabilitas pada tabel 3, diketahui bahwa variabel di atas memiliki nilai cronbach's alpha dan composite realibility di atas 0,7. Dengan nilai tersebut, maka dapat disimpulkan bawa data pada penelitian ini reliabel karena memenuhi kriteria dengan hasil yang berada di atas 0,7 (Hair et al., 2011).

Setelah pengujian outer model (validitas dan reliabilitas), pengolahan data variabelvariabel penelitian dilanjutkan pada tahapan pengujian inner model (model struktural) untuk dapat mengetahui kontribusi dari variabel-variabel independen (X) terhadap variabelvariabel dependen (Y). Kriteria pengujian model struktural yang harus dipenuhi pada penelitian ini yaitu nilai koefisien determinasi $\left(\mathrm{R}^{2}\right)$ dan path coefficients.

Hasil nilai koefisen determinasi $\left(\mathrm{R}^{2}\right)$ pada penelitian ini adalah sebesar 0,797. Artinya adalah, variasi perubahan variabel dependen sebesar 79,7\% dapat dijelaskan oleh variabel independent. Sedangkan 20,3\% dijelaskan oleh variabel diluar penelitian. Berdasarkan kriteria nilai R-Square yang dikemukakan Sarstedt, Ringle, \& Hair, (2017), pengujian koefisien determinasi mempunyai 3 kriteria yang diantaranya adalah jika nilai $\mathrm{R}$ Square 0,25 maka dikategorikan lemah. Jika nilai R Square 0,50 maka dapat dikategorikan sedang dan apabila nilai R Square 0,75 maka dapat dikategorikan kuat.

Tabel 4. Hasil Bootsrapping

\begin{tabular}{|l|c|c|c|}
\hline & Original Sample & T-Statistic & P-Value \\
\hline $\begin{array}{l}\text { Kompensasi } \rightarrow \text { Kepuasan } \\
\text { Kerja }\end{array}$ & $\mathbf{0 . 3 0 3}$ & $\mathbf{5 . 3 0 5}$ & $\mathbf{0 . 0 0 0}$ \\
\hline $\begin{array}{l}\text { Lingkungan Kerja } \\
\rightarrow \text { Kepuasan Kerja }\end{array}$ & $\mathbf{0 2 0 8}$ & $\mathbf{3 . 2 8 7}$ & $\mathbf{0 . 0 0 1}$ \\
\hline $\begin{array}{l}\text { Fasilitas } \rightarrow \text { Kepuasan } \\
\text { Kerja }\end{array}$ & $\mathbf{0 . 4 9 0}$ & $\mathbf{7 . 9 2 5}$ & $\mathbf{0 . 0 0 0}$ \\
\hline
\end{tabular}

*Sumber : olahan data Smart-PLS versi 3.00

\section{DISKUSI}

a) Berdasarkan hasil pengujian yang telah dilakukan pada setiap variabel, variabel X1 (kompensasi) terhadap Y (kepuasan kerja) memiliki nilai $t$-statistics sebesar 5,305 dan $P$ values sebesar 0,000. Dari penjelasan diatas, maka dapat dijelaskan dan disimpulkan bahwa Kompensasi memiliki pengaruh yang positif dan signifikan terhadap Kepuasan Kerja. Hasil penelitian ini juga sesuai dengan penelitian terdahulu oleh I Wayan Sudana 
and Wayan Gede Supartha yang menyatakan bahwa kompensasi memiliki pengaruh positif dan signifikan terhadap kepuasan kerja.

b) Berdasarkan hasil pengujian yang telah dilakukan pada setiap variabel, variabel X2 (Lingkungan Kerja) terhadap Y (kepuasan kerja) memiliki nilai $t$-statistics sebesar 3,287 dan $P$ values sebesar 0,001 Dari penjelasan diatas, maka dapat dijelaskan dan disimpulkan bahwa Lingkungan Kerja memiliki pengaruh yang positif dan signifikan terhadap Kepuasan Kerja. Hasil penelitian ini juga sesuai dengan penelitian terdahulu oleh I Putu Sedhana Yasa dan I Wayan Mudhiartha Utama yang menyatakan bahwa lingkungan kerja memiliki pengaruh positif dan signifikan terhadap kepuasan kerja.

c) Berdasarkan hasil pengujian yang telah dilakukan pada setiap variabel, variabel X3 (Fasilitas) terhadap Y (kepuasan kerja) memiliki nilai $t$-statistics sebesar 7,925 dan $P$ values sebesar 0,000 Dari penjelasan diatas, maka dapat dijelaskan dan disimpulkan bahwa Fasilitas memiliki pengaruh yang positif dan signifikan terhadap Kepuasan Kerja. Hasil penelitian ini juga sesuai dengan penelitian terdahulu oleh Astadi Pangarso, Fardani Fajar Firdaus, Nadya K. Moeliono yang menyatakan bahwa Fasilitas memiliki pengaruh positif dan signifikan terhadap kepuasan kerja.

Dari analisis data yang telah dilakukan, pengujian pada penelitian ini telah menghasilkan hasil yang sesuai dengan hipotesis. Hasil dari pengujian hipotesis menunjukkan terdapat pengaruh yang positif dan signifikan pada variabel Kompensasi, Lingkungan Kerja dan Fasilitas terhadap variabel Kepuasan kerja karyawan.

\section{PENUTUP}

Berdasarkan hasil penelitian dari pengujian data dalam penelitian ini menunjukkan bahwa Kompensasi, Lingkungan Kerja dan Fasilitas mempunyai hubungan yang positif signifikan terhadap Kepuasan kerja karyawan PT ISS Indonesia di Universitas Tarumanagara. Hal ini dapat terhadi karena Kompensasi, Lingkungan Kerja dan Fasilitas merupakan komponen yang cukup penting dan dapat mendukung kesejahteraan bagi karyawan sehingga dapat menciptakan kepuasan kerja sumber daya manusia.

Dalam sebuah penelitian tentunya dapat memiliki beberapa keterbatasan, begitu pula dalam penelitian ini. Keterbatasan dari penelitian ini dikarenakan: (1) Variabel yang di bahas dalam penelitian ini hanya terdiri dari 3 variabel yang mempengaruhi kepuasan kerja karyawan. Sedangkan,diketahui masih terdapat beberapa faktor lain yang dapat mempengaruhi kepuasan kerja karyawan. (2) Di dalam penelitian yang menggunakan kuisioner terkadang terdapat jawaban yang diberikan oleh responden tidak menunjukan bagaimana keadaan sebenarnya, karena peneliti tidak dapat mengontrol jawaban satu persatu terhadap responden sehingga ada kemungkinan apabila jawaban yang diberikan oleh responden tidak sepenuhnya benar. (3) Pemahaman responden terhadap butir-butir pertanyaan yang diajukan dalam kuesioner dan durasi waktu pengisian kuesioner oleh responden cukup singkat sehingga responden tidak dapat memahami secara lebih detail.

Berdasarkan hasil dan keterbatasan di atas, maka saran yang dapat diberikan untuk penelitian selanjutnya, yaitu dengan menggunakan jumlah sampel yang lebih banyak, agar hasil yang didapat lebih akurat dan dapat melengkapi serta memperkuat penelitian-penelitian sebelumnya. Penelitian selanjutnya juga dapat mengubah variabel dalam penelitian ini dengan variabel lainnya.

\section{DAFTAR PUSTAKA}


Dessler, G. (2017). Human Resource Management (15th ed.). Boston: Pearson Education. Faisal. (2005). Pengaruh Insentif \& Fasilitas kerja terhadap produktivitas.

Hair, J. F., Ringle, C. M., \& Sarstedt, M. (2011). PLS-SEM: Indeed a Silver Bullet. Journal of Marketing Theory and Practice, 19(2), 139-152.

Hasibuan, M. S. (1991). Manajemen Sumber Daya Manusia. Jakarta: Haji Masagung.

Henseler, J., Ringle, C. M., \&amp; Sinkovics, R. R. (2009). The use of partial least square path modeling in International Marketing. Advances in International Marketing, 20, 277-319.

Luthans, F. (2006). Perilaku Organisasi (10th ed.). Yogyakarta: Andhi.

Moenir. (2010). Manajemen Pelayanan Umum Di Indonesia. Jakarta: PT Bumi Aksara.

Mundung, M. (2007). Pengaruh Karakteristik Kerja, Iklim Kerja dan Kompensasi terhadap Kepuasan Kerja Karyawan Wanita (Studi pada Perusahaan Ikan Kaleng "Joint Venture" di Kota Bitung). Jurnal Ekonomi Dan Manajemen, 8.

Nitisemito, A. S. (1996). Manajemen Personalia: Manajemen Sumber Daya Manusia. Jakarta: Ghalia Indonesia.

Pioh, N. L., \& Tawas, H. N. (2016). Pengaruh Kompensasi dan Lingkungan Kerja terhadap Kepuasan Kerja dan Kinerja Pegawai ( Studi Pada Pns Di Kantor Kecamatan Sonder Kabupaten Minahasa ). Jurnal EMBA, 4(2), 838-848.

Sarstedt, M., Ringle, C. M., \& Hair, J. F. (2017). Handbook of Market Research. In Handbook of Market Research. https://doi.org/10.1007/978-3-319-05542-8

Sekaran, U., \& Bogie, R. (2013). Research Methods for Business. United Kingdom: Jhon Wiley\&Sons Ltd.

Sudana, I. W., \& Supartha, W. G. (2015). Pengaruh Kompensasi dan Lingkungan Kerja Fisik terhadap Motivasi dan Kepuasan Kerja Karyawan di Grand Puncak Sari Restaurant Kintamani. E-Jurnal Manajemen Unud, 4(7), 1865-1882.

Sunyoto, D. (2013). Sumber Daya Manusia (1st ed.). Yogyakarta: Caps.

Sutrisno, E. (2009). Manajemen Sumber Daya Manusia. Jakarta: Prenada Media Group. 